4 norden

Strategi for internasjonal profilering og posisjonering av Norden

2015-2018




Strategi for internasjonal profilering og posisjonering av Norden 2015-2018

ISBN 978-92-893-3926-1 (PRINT)

ISBN 978-92-893-3927-8 (PDF)

http://dx.doi.org/10.6027/ANP2015-705

ANP 2015:705

(C) Nordisk ministerråd 2015

Layout: Erling Lynder

Trykk: Rosendahls-Schultz Grafisk

Opplag: 400

Printed in Denmark

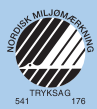

www.norden.org/no/publikasjoner

Nordisk ministerråd

Ved Stranden 18

DK-1061 København K

Telefon (+45) 33960200
Det nordiske samarbeidet

Det nordiske samarbeidet er en av verdens mest omfattende regionale samarbeidsformer. Samarbeidet omfatter Danmark, Finland, Island, Norge og Sverige samt Færøyene, Grønland og Åland.

Det nordiske samarbeidet er både politisk, økonomisk og kulturelt forankret, og er en viktig medspiller i det europeiske og internasjonale samarbeidet. Det nordiske fellesskapet arbeider for et sterkt Norden i et sterkt Europa.

Det nordiske samarbeidet ønsker å styrke nordiske og regionale interesser og verdier i en global omverden. Felles verdier landene imellom bidrar til å styrke Nordens posisjon som en av verdens mest innovative og konkurransekraftige regioner. 


\section{Strategi for internasjonal profilering og posisjonering av Norden}

2015-2018

Forord $\quad 5$

$\begin{array}{ll}\text { 1. Bakgrunn } & 7\end{array}$

$\begin{array}{ll}1.1 \text { Statsministrene } & 7\end{array}$

$\begin{array}{ll}1.2 \text { Samarbeidsministrenes visjon } & 7\end{array}$

$\begin{array}{ll}1.3 \text { Nordic Cool } & 7\end{array}$

$\begin{array}{ll}1.4 \text { Forstudie } & 8\end{array}$

2. Strategi for internasjonal profilering og

2.1 Hensikten med strategien $\quad 9$

$\begin{array}{ll}2.2 \text { Felles plattform } & 10\end{array}$

2.3 Illustrasjon, det nordiske perspektivet $\quad 11$

$\begin{array}{ll}3 . & \text { En fortelling om Norden } \\ & 13\end{array}$

4. Bruk av strategien 16

4.1 Strategiske profileringsområder $\quad 16$

$\begin{array}{ll}4.2 \text { Prioriterte geografiske områder } & 19\end{array}$

5. Målgrupper 20

6. Mål 21

7. Kriterier for vellykkede prosjekter og aktiviteter 22

8. Budsjett 23

9. Tidsplan og implementering 24

$\begin{array}{ll}9.1 \text { Implementeringsplan } & 24\end{array}$

10. Praktiske verktøy 25 


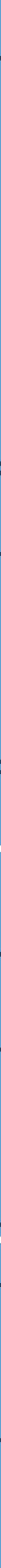




\section{Forord}

Norden appellerer. I lengre tid har nordiske kjennetegn innen kjøkkenkunst, design, film, musikk og litteratur gjort Norden anerkjent internasjonalt. Suksessene kommer fra alle de nordiske land, og mange av dem deler et nordisk snitt - en nordisk merkevare.

Internasjonalt markerte Norden seg imidlertid for alvor først i etterdønningene av den økonomiske krisen.

Denne viste at den nordiske styrings- og velferdsmodellen nok en gang hadde evnen til å fornye seg, og gjorde at stater verden over begynte å diskutere om vår modell kan fungere som en mulig buffer og stabiliserende faktor i en stadig mer usikker global økonomi.

Men også vi nordboere står ansikt til ansikt med en rekke krevende utfordringer. Vi er langt fra perfekte, og kanskje er det nettopp det upolerte som gjør oss fascinerende.

Samtidig ligger vi i toppen i internasjonale målinger av åpenhet, tillit, likestilling, miljø og nivå av lykke. Disse verdier vil vi gjerne dele med resten av verden, i tillegg til vår pragmatiske politikk, dystre krim og våre sterke kvinnebilder.

Derfor har de nordiske statsministrene ved flere anledninger ønsket at Norden i større grad skal markere seg internasjonalt. De nordiske landene har hver for seg, igjennom flere år, gjennomført vellykkede profileringsprosjekt internasjonalt. Men ut ifra statsministrenes tanke om at vi sammen er sterkere, ønsker vi nå å profilere de nordiske landene under ett.

Samlet er vi ikke bare mer slagkraftige politisk og økonomisk, men samlet kan vi også bedre bidra til utvikling i verden, og i møte med verden kan vi også selv utvikle oss.

Målet er ikke å formidle et homogent bilde av landene i Norden og gi et inntrykk av at alle Nordens innbyggere, organisasjoner og regjeringer tenker og oppfører seg likt. Men heller enn å betone landenes særtrekk, ønsker vi å underbygge det vi deler; vårt nordiske perspektiv, våre verdier og en kultur som springer ut fra en felles historie. 
Ved å systematisere og øke den nordiske synligheten internasjonalt markerer denne nye profilerings- og posisjoneringsstrategien begynnelsen på et nytt og historisk samarbeid de nordiske landene imellom.

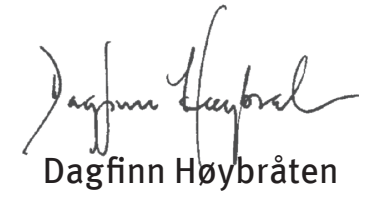

Generalsekretær for Nordisk ministerråd

\author{
Eygli Hañ \\ Eygló Harðardóttir \\ Islandsk minister for \\ nordisk samarbeid
}




\section{Bakgrunn}

På oppdrag fra de nordiske samarbeidsministrene har Nordisk ministerråds sekretariat, etter bred forankring i omverdenen, $i$ de nordiske landenes offentlige og private sektorer og internt i det nordiske samarbeidets nettverk, utviklet en strategi for internasjonal profilering og posisjonering av Norden. Sekretariatet skal administrere og koordinere arbeidet med strategien i dialog og samarbeid med landene.

Strategien setter opp noen strategiske retningslinjer for hvordan Norden og regionens interessenter skal profileres internasjonalt, og er et tilbud til alle aktører også utenfor det offisielle nordiske samarbeidet.

\subsection{Statsministrene}

De nordiske statsministrene uttalte på sitt møte i Mývatn 27. mai 2014 et sterkt håp om økt nordisk samordning og synlighet, og ga blant annet prioritet til arbeidet med regional branding for å styrke de nordiske landenes konkurransekraft og øke mulighetene for nordisk innflytelse internasjonalt.

\subsection{Samarbeidsministrenes visjon}

De nordiske samarbeidsministrenes visjonsdeklarasjon for det nordiske samarbeidet, Sammen er vi sterkere, ${ }^{1}$ peker på et innovativt, synlig og utadvendt Norden som viktige kjennetegn for samarbeidet, og understreker hvordan de felles nordiske erfaringene kan bety mye for andre $i$ en verden der betydningen av regionalt samarbeid øker. Visjonen er basert på følgende fire pilarer:

- Et grenseløst Norden.

- Et innovativt Norden.

- Et synlig Norden.

- Et utadvendt Norden.

\subsection{Nordic Cool}

Med den vellykkede storsatsingen Nordic Cool 2013 i Washington D.C. i USA som det fremste eksempelet vokste det fram en vilje til å gjennomføre flere profilerende aktiviteter som involverer en rekke parter i hele Norden. Parallelt med de sterkt profilerende kulturbegivenhetene i Kennedy Center ble det gjennomført en rekke aktiviteter for å fortelle om hva Norden kan bidra med innovativt og politisk. Takket være at dette også ble en mediesuksess, oppsto det mange ringer på vannet. Lærdommen ble også at store, felles satsinger er tids- og ressurskrevende å gjennomføre, ${ }^{2}$ og at strategisk tenkning er avgjørende.

1 Norden-Sammen er vi sterkere, de nordiske samarbeidsministrenes visjon for det nordiske samarbeidet (2014).

\section{Utvärderingav} kommunikationseffekter Nordic Cool 2013, Gullers Grupp (2013). 


\subsection{Forstudie}

En omfattende forstudie, gjennomført vinteren 2013-2014, oppfordret, $i$ tråd med samarbeidsministrenes visjon, Norden til å danne et profilerende team med nordiske og internasjonale representanter for både offentlige og private sektorer. Forstudien viste en bred støtte for en strategi. ${ }^{3}$ En strategi kan:

- sikre en konsekvent profilering av Norden

- framheve og tydeliggjøre de felles budskapene.

Flere argumenter fra forstudien for at en strategi skulle utarbeides, og hvorfor nå:

- Verden definerer Norden som en enhet - jo lenger borte geografisk sett, desto mer.

- Verden har i økende grad fått øynene opp for Norden og den nordiske modellen. Regionens anseelse har steget takket være håndteringen av finanskrisen siden 2008 og andre løsninger på velferdsproblematikken, men også på grunn av suksessene på den kulturelle, kreative og innovative arenaen.

- Både i offentlig og privat sektor er interessen stor i Norden for en felles profilering som skaper merverdi.

- Samlet topper de nordiske landene internasjonale indekser som måler åpenhet, toleranse og tillit. Internasjonale medier omtaler dette ofte i en nordisk kontekst.

- For å ta vare på det nordiske varemerkets gjennomslagskraft, få ut budskapet og oppnå det ønskede målet, må vi ta kontroll over varemerket, aktivt arbeide med det og konsekvent kommunisere et samlet og tydelig bilde. 


\section{Strategi for internasjonal profilering og posisjonering av Norden}

Verden utenfor Norden definerer i høy grad Norden som en enhet. ${ }^{4}$ Bildet er positivt, mye takket være at vi i Norden ser ut til å ha funnet løsninger på økonomiske og politiske utfordringer som både vi og andre kjemper med. Den nordiske modellen har blitt et begrep. Hvert nordisk land har bygd sin modell, parallelt med et vidtrekkende og konstant samarbeid i Norden.

For en fortsatt god utvikling i Norden er vi avhengige av hva som skjer i verden rundt oss, og av at andre er interessert i oss. Det er i vår interesse å bidra til både vår egen og andres framtid gjennom utveksling av ideer, kompetanse, erfaringer, tjenester og varer.

Konkurransen om en plass på den internasjonale arenaen er stor, og små land som de nordiske kan skape større synlighet og innflytelse i fellesskap. Med samordnede profilerende aktiviteter i et felles initiativ kan det oppstå synergier i de respektive lands offentlige og/eller private sektor.

Strategien for profilering og posisjonering av Norden setter opp noen strategiske retningslinjer for hvordan Norden og landenes interessenter skal profileres internasjonalt. Den er et første skritt i en langsiktig satsing på å systematisere og sikre en konsekvent profilering av Norden og et tilbud som støtter evnen til samarbeid i samordnet retning når dette gir merverdi for den enkelte aktør. Det finnes andre grunner til å operere internasjonalt enn profilering og posisjonering: diplomatiske grunner, erfaringsutveksling med mer. For disse gjelder ikke denne strategien.

Strategien gjelder for perioden fra 2015 til 2018, da den blir gjenstand for en grundig evaluering der forslagene til endringer avgjøres av de nordiske samarbeidsministrene (MR-SAM). Eventuelle mindre oppdateringer gjøres en gang per år og avgjøres av de nordiske samarbeidsministrenes embetsmannskomité (NSK).

\subsection{Hensikten med strategien}

Norden og de nordiske landenes konkurransekraft og internasjonale innflytelse skal styrkes ved hjelp av samordnede profilerende aktiviteter $\mathrm{i}$ et felles initiativ.

Den positive internasjonale oppmerksomheten rundt Norden og de nordiske landene skal utnyttes og ytterligere forsterkes ved at man $i$ høyere grad bruker Norden som begrep, ikke minst på markeder der kjennskapen til Norden som region er større enn kjennskapen til hvert enkelt land. Flere samordnede aktiviteter skal også styrke allerede eksisterende relasjoner $\mathrm{i}$ 
5 The Global

Competitiveness Report

2014-2015, World

Economic Forum (2014).

6 Quality of Life Index, The Economist Intelligence Unit (2014).

7 The Global Gender Gap Report 2013, World Economic Forum (2013).

8 En förstudie kring behovet av en gemensam nordisk varumärkesstrategi, Nordiska ministerrådets kommunikationsavdelning och Happy Forsman \& Bodenfors (2014). mer nærliggende geografiske områder. Strategien skal forenkle og forbedre arbeidet med profileringen og posisjoneringen av Norden internasjonalt. Den skal forklare meningen med profilering og gi støtte samt henvise til konkrete verktøy som gjøres tilgjengelige for alle parter.

\subsection{Felles plattform}

Med et felles nordisk initiativ kan hvert enkelt land eller aktør fortelle om det man faktisk ikke kan si som bare svenske, danske, nordmann, finne, islending, ålending, færøying eller grønlender. Man kan for eksempel profilere seg som del av en sterk region med 26 millioner innbyggere, et stort og variert tilbud av næringer og kultur, for ikke å snakke om en variert og fascinerende natur.

I nettopp denne sammenhengen kan Norden beskrives som et varemerke, med andre ord det samlede bildet av assosiasjoner, følelser, erfaringer og forventninger som oppstår hos mottakeren. Ingen, heller ikke et land eller en region, kontrollerer egentlig sin image - spesielt ikke i dagens transparente, raskt bevegelige og stadig mer digitale kommunikasjonslandskap. Man gjør seg fortjent til den. For langsiktige og bærekraftige relasjoner med andre land må tilbudet være ekte. Man må være det man påstår at man er og vil være.

Det som knytter de nordiske landene sammen, er det som skaper styrke nok til å tiltrekke seg interesse fra resten av verden. Etter år med tett og vellykket samarbeid er det mulig at vi i Norden tar våre felles styrkeområder for gitt. I strategien for profilering og posisjonering av Norden, som styrer hvordan vi kommuniserer hva vi er og hva vi vil, er det likevel viktig å formulere de felles fortrinnene vi mener at vi har i forhold til verden rundt oss.

Hvordan kan man forklare at de nordiske landene plasserer seg så høyt i globale rankinger over konkurransekraft, ${ }^{5}$ livskvalite ${ }^{6}{ }^{\text {og }}$ likestilling? ${ }^{7}$ Og hvordan har det seg at interessen for nordisk kreativitet og kultur er så stor akkurat nå? Det finnes en nysgjerrighet hos verden rundt oss på de nordiske landene og hvordan vi har greid å oppnå utvikling og gode resultater også i dårligere tider. ${ }^{8}$ Hvilke faktorer ligger bak? Hva er det vi gjør?

I illustrasjonen på neste side har vi satt sammen faktorer som er framhevet i denne strategiens brede forankringsprosess. Illustrasjonen kan også ses som en sjekkliste over perspektivene vi vil få fram i vår kommunikasjon og i våre relasjoner med verden rundt oss. Hver for seg er de verken unike eller revolusjonerende, men sammen viser de en nordisk måte å tenke på. Vi kaller det det nordiske perspektivet. 


\subsection{Illustrasjon, det nordiske perspektivet}

\section{BAKGRUNNSFAKTORER}

GEOGRAFI

- Store arealer.

- Tynt befolket.

- Skoger, fjell, åkre.

- Omgitt av hav.

- Tøft klima.

- Mørke vintre.

- Intensivt lys om sommeren.

SAMFUNN

- Godt utbygd sosialt sikkerhetsnett og velferdstjenester.

- Kostnadsfri utdanning for alle statsborgere.

- Høy og jevn levestandard.

- Likestilt sysselsettingsgrad.

- Et sterkt sivilsamfunn.

- Høyteknologisk og spesialisert næringsliv.

- Staten setter av store ressurser til forskning og utvikling.

\section{HISTORIE}

- Lang historie med fred i Norden (200 år).

- Tradisjon for folkebevegelser.

- Lang historie med samarbeid i Norden

- Arbeidsmarked.

- Passunion.

- Samordnede løsninger for sosial sikkerhet.

- Små samfunn har muliggjort flate hierarkier.

- Lang tradisjon for industri, innovasjon og entreprenørskap.

\section{KULTUR}

- Naturen har stor plass i:

- litteraturen

- kunsten

- arkitekturen.

- Nordisk kreativitet får oppmerksomhet:

- Nordic Noir.

- Nordic Cuisine.

- Nordic Design. 


\section{Styrker vi vil framheve}






\section{En fortelling om Norden}

Illustrasjonen av det nordiske perspektivet, som beskriver en felles plattform av delte nordiske styrker i form av kjennetegn og verdier, kan også framstilles som en fortelling. En slik fortelling kan inspirere representanter og talspersoner for Norden $\mathrm{i}$ arbeidet med å kommunisere hva Norden står for, og hva vi kan og vil i forhold til verden rundt oss.

Fortellingen, som er kort og derfor også forenklet, kan videreutvikles og kombineres med egne budskap.

\section{Det nordiske perspektivet}

På den nordlige delen av den nordlige halvkulen bor en relativt liten gruppe mennesker på store arealer forbundet med et enda større hav. Slik kan man beskrive Nordens fem land, Sverige, Danmark, Norge, Finland og Island, samt Grønland, Færøyene og Åland, med en befolkning på 26 millioner mennesker til sammen. Men for å få et komplett bilde må man legge til at landene sammen har utviklet seg til velferdssamfunn med en plassering blant de fremste økonomiene i verden.

Det tøffe klimaet med lange og mørke vintre, men også sommerens intensive lys og havets, skogenes, fjellenes og åkrenes rikdom, har skapt nordboens spesielle forhold til naturen. Et åpenbart behov for plass, for å få puste, på havet, på fjellet eller i skogen, har påvirket dagens rådende måte å forholde seg til miljøet og naturens ressurser på.

I det moderne Norden søker vi etter bærekraftige miljøteknologiske løsninger samtidig som bærekrafttenkningen også påvirker forholdet til helse og mat. Den som kommer til Norden for å arbeide, forske eller utdanne seg, oppdager hvor stor vekt næringslivet og hele samfunnet legger på mulighetene for et menneskelig og balansert liv med tid for både karriere og sosiale relasjoner. Og vi håper at den som kommer hit som turist, gjerne vil bli ambassadør for nordisk natur og kultur. 
Behöver den nordiska modellen förändras?, ETLA - Research Institute of the Finnish Economy \& Nordiska ministerrådet (2014).

10 The Nordic Way, World Economic Forum, Svenska Institutet (2012).

11 The Nordic Countries The next super model, the Economist (2013).

12 Behöver den nordiska modellen förändras?, ETLA - Research Institute of the Finnish Economy \& Nordiska ministerrådet (2014).
Forholdet til naturen, til det nordlige rommets vilkår, har stor plass også i litteraturen, musikken, kunsten, designen og arkitekturen. Kunsten og kreativiteten er virkelig det som nå bidrar til å sette Norden på verdenskartet, både den klassisk nordiske og den som påvirkes av møtet med det nye, moderne og mer flerkulturelle Norden. Etterspørselen etter det som iblant kalles Nordic Noir i litteratur og film, har aldri vært større.

Vår felles historie er langt fra ublodig, men vi kan i dag feire mer enn 200 år med fred mellom landene våre. Å gi og ta, å finne pragmatiske løsninger til samtlige parters beste, er et kjennetegn, og vi er stolte av at framtredende personer fra Norden har fått mulighet til å bidra i meklinger mellom krigende parter i vår tid. De nordiske landene vil vise engasjement og tilstedeværelse i fredsbevarende organisasjoner, vi tror på at bistand i solidaritet med verdens utsatte skaper en bedre verden, og i Norge deles det ut en fredspris til Alfred Nobels minne hvert år.

En evne til stadige reformer for å møte utfordringer i samtiden er en beskrivelse av den såkalte nordiske modellen. Forandringer $\mathrm{i}$ de brede lag av folket, som reformasjonen og folkebevegelsene, deriblant arbeiderbevegelsen, gikk historisk sett foran, men snart slo alle vakt om den. Den nordiske modellen kjennetegnes i dag av en offentlig sektor som forsyner sine borgere med velferdstjenester og et sosialt sikkerhetsnett. Arbeidsmarkedet reguleres i høy grad av kollektivavtaler som inngås mellom partene i arbeidslivet. Kombinert med sunne statsfinanser har modellen skapt rom for høy og jevn levestandard, høy og likestilt sysselsetting og omfattende satsinger på utdanning og forskning. Målet er et godt og utviklende liv for både individ og samfunn. ${ }^{9,10}$

Vi er naturligvis ikke alene om å finne nye velferdsløsninger, men likevel framheves ofte den nordiske modellen som et forbilde, som en "super model" ${ }^{11}$ Et iøynefallende eksempel er hvordan den høye sysselsettingsgraden blant kvinner både bidrar til likestilling og høy levestandard. Det sies at tryggheten det sosiale sikkerhetsnettet gir, også har bidratt til innovasjonskraften i Norden. Mennesker våger og kan tenke nytt ettersom det ikke medfører en risiko for hele tilværelsen. En kostnadsfri utdanning legger grunnlaget for et høyt og bredt kompetansenivå, og det er takket være en verdensledende satsing på forskning vi lever i moderne og høyteknologiske samfunn her oppe i nord. ${ }^{12}$

Det var engasjerte mennesker som sluttet seg sammen i foreninger og utviklet demokratiet. I små og foreningstette samfunn som de nordiske kunne man bygge flate hierarkier, og i den felles oppbyggingen av velferdsstaten stille krav om åpenhet, transparens og frihet til å uttrykke meninger i tale og skrift. Transparensen er mor 
til den lave graden av korrupsjon. Åpenheten har avfødt en tillit til andre mennesker, til politikerne og rettssystemet - en tillit som er unik i verden. ${ }^{13}$

Til tross for at hvert nordisk land har gått og går sin egen vei eksempler på det er at tre land er EU-medlemmer og de andre ikke, tre land har medlemskap i NATO og de andre ikke - fins det en ubendig vilje til samarbeid. Også her gikk folkebevegelsene foran $\mathrm{i}$ begynnelsen av forrige århundre og dannet Foreningen Norden. Etter to verdenskriger ble følelsen av nærhet og avhengighet sterkere, og et formelt samarbeid mellom både regjeringer og parlamentarikere ble innledet. Raskt, og lenge før det europeiske samarbeidet, ga det Norden en passunion, et felles arbeidsmarked og samordnede løsninger for sosial sikkerhet.

Vi har ikke bare bygd velferd i samspill med hverandre, men også med andre. Hvordan skulle små land som våre ellers kunne leve og overleve? Alltid og for alltid er vi avhengige av andres kunnskap, varer og vennskap.

Vi har lang erfaring med samarbeid for bedre vilkår, med bygging av en samfunnsmodell som tilbyr mennesker et verdig og meningsfullt liv med muligheter for utvikling, og vi tror at vi har noe å tilby dem som også søker svar på framtidens utfordringer. Det handler om alt fra ideer, kunnskap og erfaringsutveksling til innovative og bærekraftige løsninger.

Det er sagt at vi har kommet så langt ved å være nordiske, så det er rett og slett det vi skal fortsette å være - nordiske.

Vår plass på jorden og vår historie har selvfølgelig utstyrt oss med et eget og helt spesielt perspektiv. Vi gjør kanskje det samme som mange andre, men vi gjør det på vår måte, ut fra en felles plattform som definerer nettopp våre styrker.

- Åpenhet og en tro på alles rett til å uttrykke sine meninger.

- Tillit til hverandre og, takket være nærheten til makten, også til samfunnets ledere.

- Medmenneskelighet, toleranse og overbevisningen om alle menneskers likeverd.

- Bærekraftig forvaltning av naturen og utvikling av naturressursene.

- Nytenkning med satsinger på kreativitet og innovasjoner. 


\section{Bruk av strategien}

Nå som formålet med internasjonal profilering av Norden er klart og de felles verdiene vi vil kommunisere er identifisert, gjenstår det å prioritere hva som i første rekke skal kommuniseres og hvor. Et utvalg som dette skal ikke hindre andre aktiviteter, men samordnede budskap vil bli tydeligere, noe som er en forutsetning for mulighetene for å styrke posisjoner i dagens budskapssamfunn.

Her følger de nåværende prioriteringene, som et bredt spekter av offentlige og private aktører har identifisert som profileringsområder.

\subsection{Strategiske profileringsområder}

Strategiske profileringsområder for denne strategiens tidshorisont er utarbeidet med utgangspunkt i de overgripende politiske prioriteringene innenfor det nordiske samarbeidet, for tiden Holdbar nordisk velferd og Grønn vekst, samt landenes aktuelle politiske prioriteringer. Dessuten påvirkes utvalget av initiativer til storsatsinger på kulturområdet. Prioriteringene skal framheve områder som i et nordisk perspektiv kan utvikles i dialog med verden ellers, og de har to primære utgangspunkter:

1 Hva Norden kan tilby omverdenen.

2 Hvordan omverdensrelasjonene kan komme til nytte for Norden.

Visse aktiviteter vil kunne berøre ett eller muligens flere av de utvalgte profileringsområdene, andre kan berøre samtlige.

\subsubsection{Den nordiske modellen}

Siden finanskrisen 2008 har omverdenens interesse for den såkalte nordiske modellen økt markant. I korthet handler modellen om å skape rom for en høy og jevn levestandard ved hjelp av sunne statsfinanser, om å fordele velferd og sosial beskyttelse i likeverdets tegn, om et arbeidsmarked som i høy grad reguleres av kollektivavtaler som inngås mellom partene i arbeidslivet, samt om omfattende satsinger på utdanning og forskning.

Den nordiske modellen viser at likestilling fører til høy sysselsettingsgrad og til et arbeidsliv som tilbyr et godt liv etter arbeidsdagens slutt. $0 g$, at et åpent og tillitsfullt samfunn støtter opp om innovativ og kreativ tenkning. Virkningskraften i den nordiske modellen ligger $\mathrm{i}$ dens gjennomprøvde evne til å reformere seg proaktivt for å møte samtidens utfordringer. Modellen er med andre ord pragmatisk. 
Modellen bygger også på en aktiv måte å forholde seg til omverdenen på, og en overbevisning om at stabilitet er gunstig for handel, økt kunnskap, gjensidig kulturell forståelse og bærekraftig utvikling. ${ }^{14,15}$

Den nordiske modellen utvikles i harmoni med omverdenen, og vi tror at den i et internasjonalt perspektiv kan tilby løsninger på framtidige utfordringer. Derfor vil vi profilere den og gjøre den enda mer kjent, både i deler og som helhet.

\subsubsection{Norden som kunnskapssamfunn}

Et høyt kunnskapsnivå er en viktig forklaring på Nordens internasjonale posisjon. Fri tilgang til utdanning gir individet utviklingsmuligheter, noe som er fordelaktig for næringslivets konkurransekraft. Forskere og andre i kunnskapssektoren tilbys store sjanser til utvikling på sine spesialistområder takket være mulighetene til å arbeide i alle nordiske land og ikke bare i ett. På flere områder er forskningen i Norden av høy internasjonal kvalitet, for eksempel innenfor ny teknologi og infrastruktur, helse, miljø og klima, ikke minst forholdene i Arktis.

Det nordiske kunnskapssamfunnet kan både bidra med nøkler til grunnleggende utdanning for flere i verden og være en del av den verdensledende forskningen.

For å ytterligere høyne nivået på forskningen er vi avhengige av omverdenen. Ved å framheve forskeres muligheter til utvikling skal vi få flere interessert i å ville skape resultater i et internasjonalt forskningsmiljø i Norden.

\subsubsection{Nordisk kreativitet og innovasjon}

De nordiske landenes plasseringer i toppen av internasjonale målinger når det gjelder kreativitet og innovasjonskraft har røtter i den nordiske modellen. I tillegg til satsinger på utdanning og forskning åpner vårt sosiale sikkerhetssystem muligheter for å ta risiko - å våge å mislykkes. Store deler av næringslivet er spesialisert og høyteknologisk, og det er gode muligheter for å utvikle kreative og innovative kompetanser innenfor industrier.

Et ønske om en miljømessig, økonomisk og sosialt bærekraftig utvikling setter krav til internasjonalt samarbeid, og noen styrkeområder som Norden kan bidra med, er grønn teknologi/Clean Tech, bioøkonomi, digital teknologi og entreprenørskap samt helse og velferd.

14 Behöver den nordiska modellen förändras? ETLA - Research Institute of the Finnish Economy \& Nordiska ministerrådet (2014).

15 The Nordic Way, World Economic Forum, Svenska Institutet (2012). 
Kulturens plass i brede befolkningslag, dens nære tilknytning til nordiske verdier, har bidratt til utviklingen av næringene som ofte kalles kreative: litteratur, film, musikk, design, arkitektur, matkultur, dataspill med flere. I ett perspektiv er kulturen et instrument for vekst, noe flere år med framgang på området vitner om.

Ved å spille på flere strenger - profilere, søke samarbeid og gjøre forretninger - vil vi bidra til innovative og kreative løsninger som bygger på bærekraftig tenkning.

\subsubsection{Nordens kultur og natur}

Vi ser på verden fra en nordlig horisont. Det gir oss vårt perspektiv. En på mange måter felles kultur er grunnlaget for det nordiske samarbeidet og for Norden som begrep.

Idealer som åpenhet, folkelig deltakelse og nærhet til makten er byggesteiner i den nordiske modellen. Det gir de nordiske kulturytringene et spesielt uttrykk som akkurat nå og i økende grad fascinerer omverdenen og speiles i begreper som Nordic Noir, Nordic Design, New Nordic Food og The Nordic Music Wonder.

Nordboene har alltid hatt sterke relasjoner til naturen, noe som gjennomsyrer hele vår kultur, men også forholdet til naturen og miljøet. I et samspill mellom kultur, natur og samfunnsansvar streber vi etter å forvalte vår arv godt. Det felles ansvaret for de naturlige og menneskelige ressursene gjennomsyrer beslutningsprosessene i både næringsliv og politikk.

Det er bra med plass i Norden. Det er vide vidder, høye fjell, dype skoger og store hav, og mennesket står fritt til å tilbringe mye av sin fritid der ute takket være en arbeidsmarkedsmodell som gir rom for både arbeid og fritid. En bærekraftig tenkning med mennesket i sentrum påvirker politikken i store trekk.

Kulturen og naturen er sentrale i profileringen av Norden. Begge forteller historien om oss som bor her, og at den som flytter hit, er velkommen til å bli en del av det som verner vår plass på jorda. Vi tilbyr hele paletten av kultur- og naturopplevelser til turister som kommer hit, og håper at de vender hjem som ambassadører for det vi er og det vi står for. 


\subsubsection{Andre aktiviteter}

Vær klar over at valget av noen større satsinger ikke utelukker andre aktiviteter i landene, i bransjene eller innenfor det nordiske samarbeidet. Strategien skal, som tidligere uttrykt, ikke begrense de enkelte landenes eller aktørenes arbeid med å posisjonere seg og sitt. Hensikten med en felles nordisk profilerings- og posisjoneringsstrategi er å komplettere og forsterke hvert lands enkelte varemerke ved å også bidra til et tydeligere og mer konsekvent bilde av den felles regionen.

\subsection{Prioriterte geografiske områder}

Profileringsinnsatser bør fokusere på områder der de nordiske landene har tydelige globale konkurransefortrinn, og der det gir en merverdi å opptre nordisk.

Sektorspesifikke aktører koordinerer sine valg av geografiske områder ut fra omverdenens interesse for det aktuelle området.

Følgende geografiske satsingsområder er utpekt med utgangspunkt i en omfattende forankringsprosess i omverdenen, landene og de nordiske samarbeidsorganisasjonene.

\subsubsection{Nordens regionale naboer}

Det er verdt å pleie samarbeider som allerede er etablert. Det nordiske samarbeidet har flere slike med nabolandene, framfor alt i Østersjøområdet og med øvrige medlemsland i EU. Mange aktører i Norden har tette relasjoner i disse områdene, og det råder her en voksende interesse for nordiske styrkeposisjoner. Med USA og Canada finnes det allerede eksisterende relasjoner som det er verdt å intensivere.

\subsubsection{Fjernmarkeder}

Jo lenger bort fra Norden man kommer, desto mindre kjennskap fins det om de enkelte nordiske landene. Der er Norden et mer relevant begrep, og felles nordiske satsinger gjør større nytte.

Spesielt pekes det på deler av BRIK-landene (Brasil, Russland, India og Kina) samt Sør-Afrika, som har en voksende innflytelse på den globale utviklingen og betydning som mål for langvarige nordiske satsinger. 


\section{Målgrupper}

Profilering og posisjonering av land og regioner involverer mange parter, og har derfor overgripende og brede målgrupper. Derfor pekes det ikke ut spesifikke målgrupper her. Hver aktivitet er unik og må formulere sin eller sine målgrupper nøye. Kunnskap om målgruppenes konkrete behov er en forutsetning for å være interessant og relevant. Derfor skal det innenfor hvert profileringsprosjekt gjøres en grundig analyse for å identifisere relevante målgrupper. ${ }^{16}$ 


\section{Mål}

Ettersom denne strategien berører et bredt spekter av nordiske aktører og partnere med ambisjoner på ulike felt, beskrives målene overordnet uten konkrete effektmål. Hvert internasjonalt profilerende initiativ må imidlertid identifisere sine spesifikke effektmål samt følge dem opp og evaluere dem. Nordisk ministerråds sekretariat tar ansvar for en samlet evaluering og analyse av resultatene for å utvikle evnen til å drive med internasjonale profileringsaktiviteter.

Hensikten og det langsiktige målet med strategien, at Norden og de nordiske landenes konkurransekraft og internasjonale innflytelse skal styrkes ved hjelp av samordnede profilerende aktiviteter i et felles initiativ, oppnås ved at:

- Nordisk ministerråd tar et koordinerende ansvar for å samordne og systematisere initiativer som gjenspeiler den strategiske orienteringen i dette dokumentet.

- Nordisk ministerråds sekretariat utvikler en kommunikasjonsplattform i tråd med denne strategien samt praktiske verktøy som inspirerer, bistår og støtter profileringsarbeidet for alle interessenter.

- Nordisk ministerråd avsetter et sentralt budsjett som gjør det mulig å utvikle synligere og mer effektive profilerende aktiviteter.

- Aktører i det nordiske samarbeidet og i de nordiske landene tar initiativ og handler med støtte fra strategien.

Dette skal resultere i:

- Større synlighet, kunnskap om og interesse for Norden og de nordiske landene blant prioriterte målgrupper og i de prioriterte geografiske områdene.

- Stor gjennomslagskraft for de felles aktivitetene som gjennomføres.

- Påvist kostnadseffektivitet og samordningseffekter for de felles aktivitetene som gjennomføres.

Effekten skal etter denne strategiens virkningstid vurderes i en overordnet bedømmelse av effektmålene som hvert enkelt prosjekt har oppnådd. Resultatet skal være veiledende for de konkrete målene som settes i oppdateringen av strategien som blir gjennomført i 2018. 


\section{Kriterier for vellykkede prosjekter og aktiviteter}

\section{Omverdenanalyse for timing og riktige målgrupper}

Nytten blir størst når man vet at det finnes en interesse for og et behov for utveksling hos den utpekte samarbeidspartneren på stedet man har valgt. Ved å identifisere og forstå behovene i omverdenen kan man gjøre riktige prioriteringer i riktig situasjon.

\section{Bruk lokale samarbeidspartnere}

Profilering skjer helst i samarbeid med en lokal partner, som hjelper til med å formidle budskapet. Erfaringer viser at troverdigheten og gjennomslagskraften blir større når profileringen også skjer via en annen part. Et eksempel var Kennedy Center, som var helt avgjørende for suksessen Nordic Cool 2013.

\section{Tenk større og grenseoverskridende}

Alle land og regioner er aktive på mange arenaer og i alle kanaler. Informasjonsstøyen er enorm. Samordnede og verdiskapende aktiviteter med gjennomarbeidede budskap krever mer arbeid, men gir større gjennomslag og ytterligere synergier.

\section{Langsiktighet, planlegging og forankring}

Enkeltstående og tilfeldige satsinger fører ikke til noe. "Det er penger ut av vinduet." Langsiktig planlegging av flere og forskjellige, men samordnede innsatser gir resultater. Tenk profilering som en mulighet i all virksomhetsplanlegging og start samarbeidet i tide. God samordning i gruppen av aktører er avgjørende.

\section{Evaluer og slipp ikke taket.}

Målinger og evalueringer høyner kompetansen og legger grunnen for stadige forbedringer. Erfaringsutveksling på nordisk nivå bidrar til mer kunnskap enn den enkelte nasjonale. Ved å bygge videre på relasjonene som hver aktivitet har gitt opphav til, skapes langsiktige og nyttige relasjoner. 


\section{Budsjett}

Fra og med 2016 etableres det en sentral budsjettpost for det koordinerende arbeidet med å identifisere, forberede og samordne større profilskapende internasjonale satsinger, og deretter bidrar relevante offentlige og private sektorer til at de gjennomføres.

Nordisk ministerråds sekretariat har ansvar for å opprettholde profesjonell kompetanse på profileringsområdet samt for å samordne og utarbeide felles kommunikative produkter og praktiske verktøy. Det dannes en rådgivende gruppe med oppdrag å kvalitetssikre de utvalgte aktivitetene slik at de gjennomføres i tråd med profileringsstrategien. Gruppen består av profesjonelt kompetente representanter fra hvert nordisk land. 


\section{Tidsplan og implementering}

Strategien gjelder fra 2015 til 2018. Strategiens aktivitetsplan og øvrige praktiske verktøy oppdateres løpende og minst en gang i året. Langsiktighet og kontinuitet er viktig, men det er behov for en årlig oppdatering for å kunne ivareta nye muligheter og gradvis konkretisere strategiske prioriteringer basert på resultater og erfaringer.

2015 blir implementeringsåret for strategien og verktøyene i den. I en første innledende fase oversettes strategien til de nordiske landenes språk samt til engelsk. Deretter sendes den formelt ut til aktørene som har bidratt under utarbeidelsesprosessen inklusive forstudien.

I denne fasen påbegynnes arbeidet med å utvikle og systematisere verktøy og annet materiale som støtte til arbeidet med internasjonal profilering og posisjonering av Norden. I fase to gjøres verktøyene tilgjengelige på www.norden.org og implementeres i nettverket. Nordisk ministerråds sekretariat tar ansvaret for implementeringen innenfor det nordiske samarbeidet samt bistår i implementeringen $i$ landene og hos andre aktører.

\subsection{Implementeringsplan}

- 27. oktober 2014: De nordiske samarbeidsministrene fatter vedtak om en strategi for internasjonal profilering og posisjonering av Norden.

- November-desember 2014: Strategien oversettes til de nordiske språkene samt engelsk.

- Januar 2015: Strategien sendes ut til samtlige relevante aktører.

- 2014-2015: Produksjon av materiale og verktøy (kommunikasjonsplattform, nett, publikasjoner, statistikk, maler og øvrige verktøy).

- Medio 2015: Det arrangeres workshops for å implementere strategien og verktøyene.

- Identifisere større innsatser for 2016-2018 (merk at Danmark som formannskapsland 2015 allerede har gjort noen prioriteringer). 


\section{Praktiske verktøy}

Nordisk ministerråds sekretariat har en underlettende og koordinerende rolle i det felles strategiarbeidet. Dette skal bidra til å kvalitetssikre satsingene og innebærer et ansvar for å tilby og samordne praktiske verktøy. Hensikten er å utarbeide verktøy som inspirerer, bistår og letter profileringsarbeidet for alle interessenter. Verktøyene kan brukes i sin helhet eller kombineres med egne budskap og verktøy.

\section{Følgende verktøy skal gjøres tilgjengelige:}

\section{En kommunikasjonsplattform}

Hensikten med en kommunikasjonsplattform i tråd med profileringsstrategien er å støtte aktørers evne til å kommunisere og levendegjøre Norden internasjonalt og å sikre en strømlinjeformet kommunikasjon. Plattformen inneholder:

- En oversiktlig og kort beskrivelse av Nordens styrkeposisjoner, jf. strategien.

- Mal for kommunikasjonsprosess.

- En sjekkliste for vurdering av framtidige initiativer til prosjekter.

- Retningslinjer for effektmål.

- Retningslinjer for å identifisere målgrupper.

- Bruk av den nordiske fortellingen.

En aktivitetsplan for felles satsinger

Kartlegging av profileringsaktiviteter og aktiviteter som har posisjonerende og profilerende potensial samt bl.a. kartlegging og eventuell samordning av nordiske ministerdelegasjoner for å effektivt samordne profileringsfremmende reiser.

\section{Mal for større profilerende prosjekter}

En veldefinert set-up (mal) som omgående kan aktiveres i forbindelse med vedtak om å gjennomføre større internasjonale profilerende prosjekter. Dette vil bygge på resultatet fra et av prosjektene under det danske formannskapet 2015 samt på erfaringer fra arbeidet med Nordic Cool 2013.

\section{Aktuell nordisk statistikk og landinformasjon}

Det utarbeides et verktøy for å importere og vise oppdaterte fakta og statistikk. De nordiske landene rangeres for eksempel høyt i internasjonale målinger, som også skal gjøres tilgjengelige. 
Oversikt og oppdatert informasjon om nordiske styrkeområder og suksesshistorier - Nordic Talking Points

En oversikt og kort presentasjon av nordiske kjerneverdier og styrkeposisjoner som støtte for kommunikasjonsarbeidet, kategorisert etter de strategiske profileringsområdene.

Kunnskapsbank i form av erfaringer fra gjennomførte aktiviteter For å dele erfaringer, analyser og målinger som gjennomføres i forbindelse med posisjons- og profilrelaterte prosjekter. 


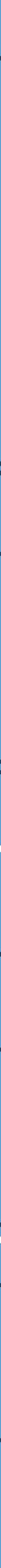




\section{norden}

Nordisk ministerråd

Ved Stranden 18

DK-1061 København K

www.norden.org

\section{Strategi for internasjonal profilering og posisjonering av Norden}

Norden appellerer. I lengre tid har nordiske kjennetegn innen kjøkkenkunst, design, film, musikk og litteratur gjort Norden anerkjent internasjonalt. Suksessene kommer fra alle de nordiske land, og mange av dem deler et nordisk snitt - en nordisk merkevare.

Internasjonalt markerte Norden seg imidlertid for alvor først $\mathbf{i}$ etterdønningene av den økonomiske krisen.

Denne viste at den nordiske styrings- og velferdsmodellen nok en gang hadde evnen til å fornye seg, og gjorde at stater verden over begynte å diskutere om vår modell kan fungere som en mulig buffer og stabiliserende faktor i en stadig mer usikker global økonomi. 